\title{
THE NIGHT-TIME ECONOMY AND SUSTAINABLE TOWN CENTRES: DILEMMAS FOR LOCAL GOVERNMENT
}

\author{
M. ROBERTS ${ }^{1} \&$ G. GORNOSTAEVA ${ }^{2}$ \\ ${ }^{1}$ Central Cities Institute, University of Westminster, UK. \\ ${ }^{2}$ Cities Institute, London Metropolitan University, UK.
}

\begin{abstract}
The state of many British town and city centres in the evening and at night is a cause for concern. In the early 1990s, a vision was introduced for Jane Jacobs' inspired mixed-use centres with the encouragement of a café culture The central quarters of many towns and cities enjoyed a brief period of 'renaissance', only to find that this was being rapidly undermined by a proliferation of bars, pubs and nightclubs fuelled by the British practice of youthful binge drinking. This article reports the findings of a postal survey and other secondary evidence that reveals the conflicts and tensions that lie at the heart of problems associated with British town centres during the hours of darkness. The dilemma for the local government lies in how to achieve a measure of urban sustainability in their central quarters that balances the benefits of increased economic activity with the negative externalities produced by an increase in alcohol-based night life. It is suggested that this dilemma of sustainability is not unique to England, but may be seen as a problem with an international dimension.

Keywords: alcohol, drinking, local government, night-time, sustainability, town centres.
\end{abstract}

\section{INTRODUCTION}

Over the last decade, many British town and city centres have undergone a transformation. This transformation has been experienced in different stages in different places. In the early 1990s, the consultancy, Comedia [1] described a situation where centres were deserted at night save from young 'lager louts' moving from pub-to-pub. Then followed regeneration initiatives [2] and in certain centres, mixed-use quarters emerged with new cultural attractions, cutting edge late night bars and clubs, restaurants, and 'loft' apartments. (See Hobbs et al. [3] for a discussion of the regeneration of central Manchester.) The private sector swiftly realised that profits were to be made and thereon followed what has been described as a 'relentless expansion' of night life with corporate providers taking over smaller operators and expanding venues into large-scale 'drinking factories' $[4,5]$. Venues that cater for a youth market, particularly of 'vertical drinkers' have dominated provision. Centres are going through different trajectories with some secondary towns moving straight from small pubs and lager louts to a domination of late-night bars and others hosting quarters that are still considered to be 'cutting edge cool'.

Until 2004, this transformation evoked little response at a national level. Academic research and the proposal to introduce new liquor licensing legislation provoked some interest. The House of Commons of the British Parliament conducted a scrutiny committee inquiry into the evening economy and the urban renaissance [6]. The Inquiry heard evidence from local authorities, the police, trade organisations, health charities, residents and other pressure groups about the threats posed to the revitalisation of town centres by the expansion of what has come to be known as the 'night-time economy'. Anecdotal evidence was brought forward about the problems of litter, noise, and cleansing, as well crime and disorder [7].

Since that initial hearing, concerns about crime and violence associated with binge drinking encouraged by the night-time economy have grown and a national newspaper subsequently launched a 'campaign' early in 2005. Newspapers and TV documentaries started to highlight the issue throughout 2004. In January 2005 a 'red top' newspaper, the Daily Mail, started a 'campaign', to combat 
the Licensing Act 2003, which was due to be fully implemented in November 2005. Fears about the night-time economy were heightened as the impacts of the full implementation of the Licensing Act 2003, a new law which liberalises pub opening hours, were anticipated. Whilst violent crime is undoubtedly important, this article pays attention to other aspects of the problems that are of equal concern to local councils and that have received less publicity. Issues such as transport, cleansing and noise also directly threaten the social and environmental quality of town and city centres, leaving local authorities to deal with the challenge of how to govern processes that ultimately may erode the sustainability of their centres. The article reports the findings of a postal survey of local authorities that was completed in the spring of 2004. Following its publication, other less comprehensive data has emerged in the form of local authority reports and policy statements and publications from political lobby groups and charities. In addition, the British Government itself has issued nationally gathered statistics and other policy and discussion documents connected with the issue. Where appropriate, the findings of the survey will be discussed in the context of these secondary sources. Finally, the problems that English town and city centres are experiencing will be considered in a wider, international context.

\section{THEORETICAL BACKGROUND}

The problems provoked by a dramatic expansion of the night-time economy would appear to fall into the framework of urban sustainability. However, there is no contemporary literature that directly addresses this link. Definitions of sustainable development and urban sustainability do refer to social and economic issues, but mainly in relation to the concept of an 'ecological misbalance' that is typical of urban areas. 'Urban sustainability', for example, is related to the goal of 'improving the social and economic conditions of an increasingly urbanised population while preserving life systems and maintaining environmental quality' [8]. The same document claims that 'sustainability is a chaotic concept plunging into meaninglessness, at best, and becoming a catchphrase for political demagoguery, at worst' (p. xx). This underlies an argument that sustainability, as a concept, is poorly theorised.

The most commonly cited definition of sustainability comes from the Brundtland Report, published in 1987. This defines sustainable development as 'Development which meets present needs without compromising the ability of future generations to achieve their own needs and aspirations' [9]. The Brundtland Report drew its observations from the environmental deterioration caused in developed countries by high-consumption lifestyles and their associated economic activities.

Key writings on sustainability neither consider the interrelationships between social, economic, political, and environmental processes nor engage fully with theories of society and space [10-16]. There are two major approaches to urban sustainability: the first places an emphasis on sustainable development and its management and is focused at a global scale, making reference to big players and the agenda of the market, top-down planning and designer-based solutions. At the local scale, sustainability deals with 'sustainable livelihoods'. This refers to processes of social and ecological reproduction situated in diverse spatial contexts.

Definitions of sustainability vary in relation to the perspectives of individuals or groups occupying varying social, economic, political and spatial positions and they differ according to what is to be sustained [8]. In some definitions, cities are considered as resources themselves, providing economic and social prosperity. In this type of thinking, the notion of a diverse and dense urban environment is strongly related to its vitality and consequently to the concept of urban sustainability.

Increasingly, attention is being paid to non-ecological and even non-economic aspects of sustainability, e.g. 'cultural identity', and 'life-style' issues [11]. In this perspective, urban sustainability should be considered as a process rather than a set of norms and in any particular situation the 
question should be asked - what exactly is it that we have to sustain? It is also important to bear in mind that ideas about the sustainable city and appropriate tools with which to govern sustainability change with time.

Jacobs' [17] critique of modernist town planning specifically referred to the economic and social continuity of urban neighbourhoods, despite her writings preceding the concepts of sustainability. It is for this reason that Jacobs developed the proposition that urban neighbourhoods should contain a 'fine-grain' of mixed uses accommodated in buildings of mixed ages and values connected by a clearly defined and naturally surveilled public realm. In her view, local governance should support processes of gradual rather than 'cataclysmic' change, whereby new businesses could start up and replace existing ones that have expanded and moved out. Jacobs' most well-known passages in relation to the night-time economy are those where she refers to the 'ballet of the street' and argues that there should be a continuity of activity and occupation in the street over an 18-hour period during the day, evening and part of the night. It is for this reason that urban theorists adopted her ideas and argued for revitalisation of urban centres at night [18, 19]. More recently, in British urban policy, the Urban Task Force [20], argued for 'an urban renaissance', for a mix of uses to be achieved as far as possible in the context of a compact city.

Whilst the focus was on a Jacobs' inspired vision of diverse neighbourhoods, less attention was paid to her comments on the way in which diversity could 'self-destruct' through the over-domination of one profitable land use. Jacobs suggested four conditions to prevent such self-destruction. These were zoning, differential taxation, public building policies and permission to expand diversity into new locations.

There is some convergence between these ideas and later concepts of urban sustainability based on 'sustainable livelihoods' which suggest that sustainable communities are those which are robust and flexible in problem solving when unsustainable processes take over, and have decision makers empowered by diverse local knowledge. They also support Jacobs' argument that sustainability is fundamentally a political process, rather than a technological or design problem. This decisionmaking process has to take into account the interests of different groups in the neighbourhood such as established residents, incomers, who may be gentrifiers, small and medium sized enterprises and the larger commercial interests. In this perspective, the ultimate threat is that the domination of nighttime entertainment uses, such as bars, nightclubs and restaurants, would make a neighbourhood unsustainable because the associated noise, litter and disorder would drive residents away and cause other businesses to leave. The conflicts between economic growth and environmental sustainability have been noted in other contexts such as Couch and Dennemann [21], who concluded that in processes of regeneration, policies on sustainability give way to prioritising economic growth.

At a more general level, the problems of the unsustainable condition of urban centres affected by an uncontrolled night time economy can be tackled, first of all, by identification of goals. These might include the identification of which groups and which lifestyles should be sustained and specify how to reach a consensus between the contradictory interests of different groups of people. The survey below represents the views of only one part of the equation - local authorities themselves - on the problems of urban sustainability and balancing quality of life in the central quarters of cities.

\section{BACKGROUND TO SURVEY}

The evidence submitted to the House of Commons Inquiry into the Evening Economy had highlighted the differential experience of localities throughout Britain of their evening and late- night economies. To gain a better understanding of these experiences, a more rigorous method of inquiry was sought. The postal survey of all local authorities in England formed the first stage of a longer three-year research-action project to investigate good practice in the management of the evening 
and night-time economies in town centres. The project is sponsored jointly by a British government department, the Office of the Deputy Prime Minister (ODPM) [22], and private sources. The survey was commissioned by the lead partner in the project, the Civic Trust - a charitable organisation that represents civic societies throughout Britain. The specific funding for the survey came from the government and the Institute for Alcohol Studies, which is also a charitable organisation and has its roots in the temperance movement. The Institute placed no pressure on the researchers over the type, extent or content of the questions. Advice was sought on the framing of the questions by a number of different stakeholders.

The survey was posted in December 2003 to all 383 local authorities in England, the area within the ODPM's authority. (Since devolution, the ODPM has jurisdiction only over English local authorities.) It was decided to survey all authorities and not just urban centres, because newspaper reports had commented problems of disorder in small coastal towns and the Inquiry had heard evidence of problems in sub-centres. The survey was followed up by telephone calls to ensure an adequate rate of return.

The response rate was normal for postal surveys, with 89 responses received comprising $23 \%$ of the total. To account for the diversity of local authorities in terms of their geography and economic profile, which influences the character of their urban centres, we used a simple classification for the analysis of the results. The primary basis for this classification ('urban', 'rural', 'deep rural') is the categorisation of wards developed by Craig [23]; it is based on the 1981 OPCS definition of urban areas, essentially a physical measurement of the built-up area within the ward. Wards fall into six groups: two termed 'predominantly rural', two 'mixed' and two 'predominantly urban'. This classification has been developed further by Bromley [24]. Here 'deep rural areas' are those with more than a third of their population in predominantly rural and a half or more in mixed or rural wards. These are mainly remote, sparsely populated, agricultural or upland/tourist areas. London boroughs were traditionally divided into Inner London (more densely populated areas with a majority of places of work and entertainment) and Outer London (mainly suburban areas).

The responses were received in a geographical spread in which all regions in England were represented. The majority of the responses were from Inner London (12.4\%), Outer London (12.4\%) and urban areas (47.2\%) which when combined comprise $72 \%$ of the total. Nevertheless, rural and deep rural areas were also represented making up the remaining $28 \%$.

\section{EXTENT OF GROWTH IN THE EVENING AND NIGHT-TIME ECONOMIES}

The picture that emerged was of expansion of night-time economy, but which was unevenly distributed. Nearly all London authorities had experienced 'significant growth'. Similarly, almost all respondent authorities in the southeast and northwest had seen growth in their night-time economies. Those not experiencing expansion include a mixture of urban and rural authorities and the remaining respondent London boroughs (see Table 1).

These responses corroborate the observations made by other researchers about the expansion of nightlife' and provide greater depth, since previous studies have been carried out in major urban centres [25]. There are several reasons for the expansion of night-time economy, which include an increase in the number of premises, increased capacity of premises, expansion of individual venues; all supported by the demands of a flourishing culture of entertainment with an emphasis on binge drinking.

\subsection{Increased number of premises}

In 2004, the cultural ministry of the British government (DCMS) reported for the first time the results of its liquor licensing statistics, which are collected once every three years. The results for England 
Table 1: Has there been a significant growth in evening/latenight activities in your area in recent years?

\begin{tabular}{lccc}
\hline & No & Yes & Total \\
\hline Deep rural & 0.0 & 100.0 & 100 \\
Outer London & 0.0 & 100.0 & 100 \\
Inner London & 9.1 & 90.9 & 100 \\
Urban & 14.3 & 85.7 & 100 \\
Rural & 23.8 & 76.2 & 100 \\
Grand total & 13.5 & 86.5 & 100 \\
\hline
\end{tabular}

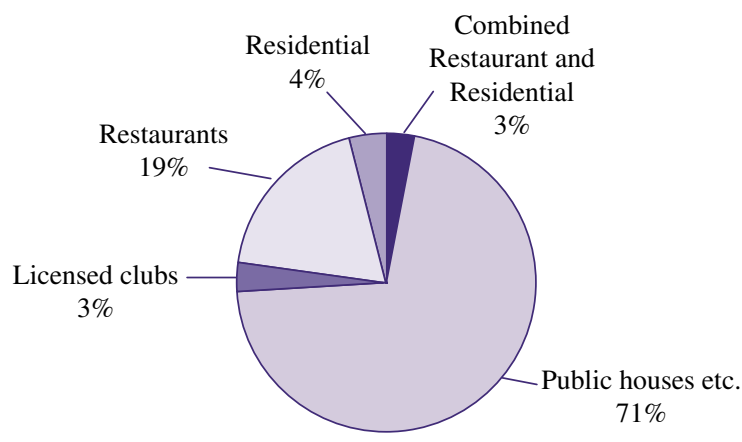

Figure 1: On-licensed premises by type, England and Wales, June 2004. Source: DCMS [27], p. 4.

and Wales demonstrated an increase, year on year of the numbers of licensed premises. Applications for 'on-licenses' (liquor licenses where alcohol is to be consumed on the premises) have increased by 145\% between 1983 and 2003 [26]. The majority of these premises are located in pubs and bars, as the pie chart in Fig. 1 illustrates.

The DCMS research points out that the highest density of licensed premises are to be found, on the one hand, in central London and, on the other, in more rural locations, such as Cumbria (the northwest of England, includes the Lake District), North Yorkshire and Devon and Cornwall. High rural densities are unexpected because it would seem that the greatest densities of licensed premises would be present in metropolitan centres outside as well as inside London. The DCMS document explains their presence as being related to tourism. The same factor would also explain our own survey findings of an expansion in the night-time economy in the responses from the 'deep' rural authorities. That Outer London boroughs had experienced expansion is also unsurprising in that with high concentrations in central London, it is likely that more premises will open in the outer suburbs.

The aggregated figures from the national statistical returns and the responses from our own postal survey do not elaborate the growth in the number of licensed premises in particular neighbourhoods within urban centres, nor the increase in the capacities of particular types of premises. Statistics are not reported on a systematic basis and evidence of a more dramatic increase in these local centres can only be gleaned from individual reports and policy documents. In Manchester, for example, the numbers of licensed premises have increased by $240 \%$ since 1998 [28] . 
4.2 Increased capacity of premises and expansion of individual venues

Figures for numbers of licensed premises mask increases in the capacities of certain types of venues. One of the impacts of a corporate encroachment into nightlife has been an expansion of individual venues in high streets and city centres (see Fig. 2). The origins for these venues lie in the 'rave' scene of the 1980s, where thousands of young people gathered together illegally on the farmland and common land out in the countryside to dance to music and party. Corporate owners have been able to exploit this phenomenon by expanding their premises and, in particular, their dance floors. The turn of the century has seen expansion in the capacities of nightclubs and what are now termed 'superpubs', such that a club or bar located in a converted cinema, or bank building, with a customer capacity of 1,000 plus is now a normal feature of town and city centres. Increases in the capacities of licensed premises therefore provide a clearer picture of the challenges that are likely to be posed in terms of public order and environmental impact. In the centre of Nottingham, for example, there are 365 licensed premises within 1 square mile and between 1997 and 2003 the number of places available for drinking increased from 66,000 to 110,000. The Association of Chief Police Officers point out that this is not just a large town phenomenon, in one small town the numbers increased from 7,000 to 15,000 over the same period [29].

In attempting to ascertain the extent of growth a distinction was made between the evening and night-time economies because it could have been possible for a locality to have been experiencing a growth in late night activities, after midnight, and not in evening activities, defined as before midnight. No authority made a response that indicated a growth in their evening economy without a commensurate rise in their late night economy. This is supported by national statistics which record that of the 113,000 on-licensed premises currently in England and Wales, 12,200 have Special Hours Certificates that permit them to open beyond the terminal hour of 11 p.m. Premises with Special Hours are not, however, widely dispersed across the country, but often clustered together. For example, Westminster City Council, which includes London's West End, the capacity of premises with late licenses in their 'Stress Areas' (West End, Edgware and Queensway/Bayswater) in 2003 was 63,679 with a closing time of 1 a.m., 20,385 with a closing time of 4 a.m. and 12,529 at 6 a.m. [30].

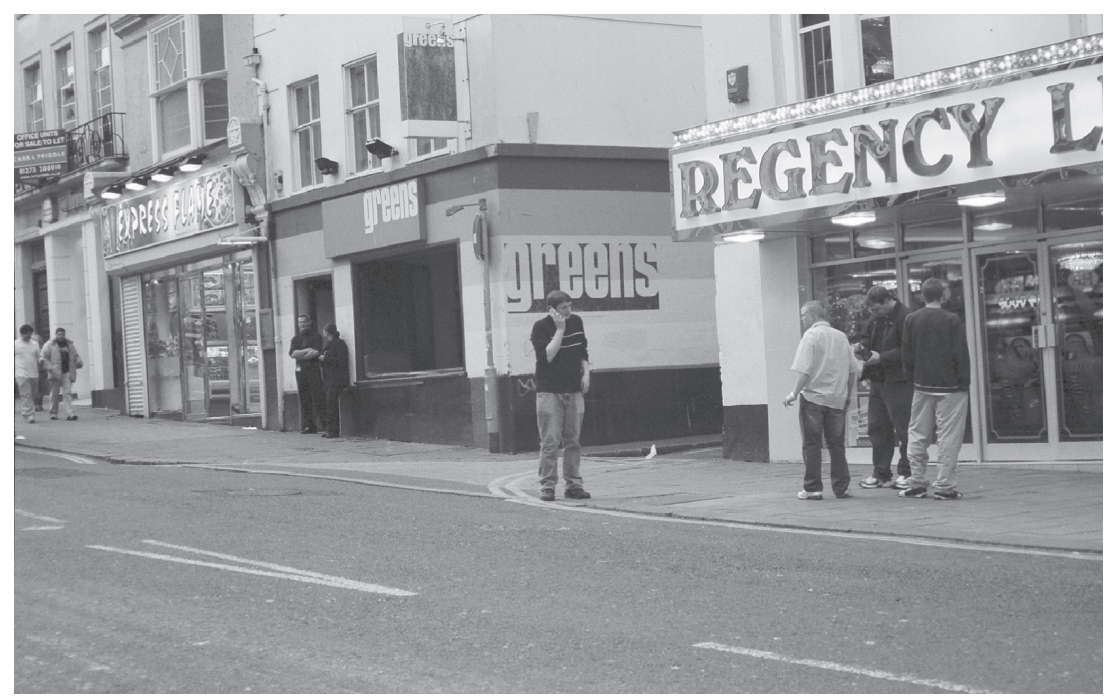

Figure 2: Concentration of venues in Brighton's West Street. 


\section{BENEFITS OF EXPANDING THE NIGHT-TIME ECONOMY}

The academic literature would suggest that the primary goal, for local authorities, in encouraging the night-time economy was to improve urban sustainability through attracting new businesses and expanding existing, attracting tourists and new residents and making city centres safer and more 'vibrant'. Most of the respondent local authorities perceived an expansion in the night-time economy as bringing benefits to their localities. These are set out in Table 2.

Among the local councils $46 \%$ regarded an improvement in vitality of their areas as being the main benefit of increased night-time activities. One Inner London authority saw expansion as 'increasing facilities for residents and boosting the Borough's cultural economy'. Over time, such an increase in vitality might bring other benefits, such as a growth in non-alcohol-based activities.

Among the respondents $37 \%$ perceived an 'increased number of jobs' as a benefit. This positive effect was reported mainly by the Inner London boroughs (54.5\%), and also by Outer London boroughs and other urban areas. In these areas, an expansion of the night-time economy has sometimes been pursued as a conscious regeneration strategy where traditional sources of jobs have been in decline through industrial re-structuring [31].

The Greater London Authority carried out a wide-ranging study of London's leisure economy [32]. The study found that each ward had gained on average 20 bar jobs in the period 1995-2000, representing a total increase of $12 \%$. In actuality, London's bar jobs were concentrated in particular areas, not only in central areas but also in micro-districts that have been the subject of regeneration and/or gentrification. Jobs in restaurants also increased by $28 \%$ and provided 'one of London's best sources of employment growth' (p. 35).

A study carried out in the rural market town of Cheltenham, which has experienced a rapid expansion in the night-time economy, also reported an increase in the number of jobs. The authors of the

Table 2: What are the main benefits associated with evening/late night activities in your area?

\begin{tabular}{|c|c|c|c|c|c|c|c|c|}
\hline & Benefit & Type of benefit & 1 & 2 & 3 & $4+5$ & NA & Total \\
\hline 1 & $\begin{array}{l}\text { Improvement in vitality } \\
\text { of the area(s) }\end{array}$ & $\begin{array}{l}\text { Greater footfall, } \\
\text { enhanced perception of } \\
\text { place }\end{array}$ & 4.5 & 14.6 & 28.1 & 46.1 & 6.7 & 100 \\
\hline 2 & Increased number of jobs & Economic & 4.5 & 15.7 & 34.8 & 37.1 & 7.9 & 100 \\
\hline 3 & $\begin{array}{l}\text { Attraction/expansion of } \\
\text { leisure venues (cinemas, } \\
\text { theatres, gyms, cyber } \\
\text { cafés) }\end{array}$ & $\begin{array}{l}\text { Development of } \\
\text { non-alcohol-based NTE }\end{array}$ & 12.4 & 25.8 & 25.8 & 29.2 & 6.7 & 100 \\
\hline 4 & $\begin{array}{l}\text { Greater number of } \\
\text { tourists }\end{array}$ & Economic & 19.1 & 31.5 & 20.2 & 20.2 & 7.9 & 100 \\
\hline 5 & New residents moving in & $\begin{array}{l}\text { Mixed use, sustainable } \\
\text { neighbourhoods }\end{array}$ & 36.0 & 22.5 & 18.0 & 11.2 & 12.4 & 100 \\
\hline 6 & $\begin{array}{l}\text { Inward investment in } \\
\text { other businesses }\end{array}$ & Economic vitality & 29.5 & 23.9 & 3.4 & 10.2 & 33.0 & 100 \\
\hline 7 & $\begin{array}{l}\text { Increased perceptions of } \\
\text { safety }\end{array}$ & $\begin{array}{l}\text { Enhanced perception of } \\
\text { place }\end{array}$ & 49.4 & 18.0 & 13.5 & 7.9 & 10.1 & 100 \\
\hline
\end{tabular}

Respondents were asked to score on a scale where $1=$ no benefit and $5=$ extremely beneficial. $\mathrm{NA}=$ not applicable . 
study went on to identify further benefits to the local economy across the supply chain, such as an increase in the retailing of fashion and fashion accessories. More opportunities for entrepreneurs associated with the music and fashion industries were also noted [33].

Among the respondents to our survey $25 \%$ reported an increase in non-alcohol-based leisure venues, such as cinemas, theatres, and gyms. A diversification of the evening economy through an expansion of leisure venues other than drinking and eating places, was recorded as beneficial and extremely beneficial by $54.5 \%$ of Outer London boroughs and other urban areas. This was perceived as being less important by the Inner London authorities, probably because many parts of Inner London already have a well-developed evening economy. One London authority that suffers from high levels of social deprivation reported that the expansion of the night-time economy in one of its minor centres had proved a 'useful marketing tool', presumably for boosting the borough's image.

It seems that very few local authorities reported that expanding their night-time economies increased perceptions of safety. This lies in direct contradiction to previous conventional thinking expressed in Planning Policy Guidance 6 (now revised) about 'crowding out crime' [34]. It would seem that the presence of people on the street only heightens a sense of safety if they are sober. However, we have to recognise that empty and overcrowded streets provide situational opportunities for different types of crime. As Hillier [35] has noted, empty streets provide opportunities for more serious crimes against the person, such as assault, whereas overcrowded streets provide 'a cover' where stealing wallets and handbags can prevail.

A relatively small proportion of authorities mentioned new residents moving in as a benefit. The last decade has seen a relative resurgence of city centre living in Britain, for example 25,000 people are current living in the 'heart' of the northern, formerly industrial city of Manchester compared to 90 in 1990 and the population of the central area of a similar city, Liverpool, has increased fourfold [36]. That few local authorities mentioned this as a benefit in response to a questionnaire directed at the night-time economy can be explained by the conflicts that are reported in the section that follows.

\section{PROBLEMS}

It would seem that despite best intentions, expansion in the night-time economy has led to as many, if not more, problems than benefits. The night-time economy has produced unintended effects such as causing nuisance for residents, increasing a sense of threat and reducing a sense of safety related to the types of crime typical of overcrowded streets and large number of drinking venues, e.g. fights, drug dealing, prostitution and vandalism. An expansion in night life has increased pollution in the streets and induced multiple transport problems. Respondents were asked to grade their responses on a scale of $1-5$, where 5 was classified as a very serious issue and 1 not a problem. Grades 4 and 5 were amalgamated as a 'major issue'. Of the responding authorities $74.2 \%$ agreed that the development and management of evening/late night activities were now considered to be a major issue in their area. Those disagreeing included mainly deep rural areas and some parts of Inner London (see Table 3).

Table 4 sets out the most interesting results of the survey from an environmental point of view. These illustrate that the problems that local authorities experience with most severity relate to infrastructure and services and not to crime. The most serious problem recorded was of insufficient public transport at night. This was reported as a severe problem in the Outer London boroughs $(63.6 \%)$, on the one hand, and in rural areas (61.9\%), on the other. Both Outer London boroughs and rural areas tend to be highly dependent on buses and private cars. The public transport network for London is radial and inner areas are better served by different modes of public transport. Even so, $45.5 \%$ of respondents from Inner London described the transport problem as being serious or extremely 
Table 3: Is the development/management of evening/latenight activities now considered to be a major issue in your area?

\begin{tabular}{lrccc}
\hline & No & Not particularly & Yes & Total \\
\hline Outer London & 0.0 & 9.1 & 90.9 & 100 \\
Urban & 4.8 & 19.0 & 76.2 & 100 \\
Rural & 0.0 & 28.6 & 71.4 & 100 \\
Inner London & 0.0 & 36.4 & 63.6 & 100 \\
Deep rural & 25.0 & 25.0 & 50.0 & 100 \\
Grand total & 3.4 & 22.5 & 74.2 & 100 \\
\hline
\end{tabular}

Table 4: Do evening/late-night activities cause significant problems in your area or raise significant issues?

\begin{tabular}{|c|c|c|c|c|c|c|c|c|}
\hline & Issue & Type of problem & 1 & 2 & 3 & $4+5$ & NA & Total \\
\hline 1 & $\begin{array}{l}\text { Insufficient public } \\
\text { transport at night }\end{array}$ & $\begin{array}{l}\text { Transport, } \\
\text { public, private }\end{array}$ & 2.2 & 16.9 & 25.8 & 52.8 & 2.2 & 100 \\
\hline 2 & Litter/rubbish on streets & Waste management & 4.5 & 27.0 & 33.7 & 33.7 & 1.1 & 100 \\
\hline 3 & $\begin{array}{l}\text { Fouling of streets, } \\
\text { public spaces }\end{array}$ & $\begin{array}{l}\text { Anti-social } \\
\text { behaviour }\end{array}$ & 10.1 & 25.8 & 30.3 & 30.3 & 3.3 & 100 \\
\hline 4 & $\begin{array}{l}\text { Area feels } \\
\text { threatening or } \\
\text { unsafe }\end{array}$ & $\begin{array}{l}\text { Perception of } \\
\text { place }\end{array}$ & 12.4 & 20.2 & 34.8 & 29.2 & 3.3 & 100 \\
\hline 5 & $\begin{array}{l}\text { Noise disturbing } \\
\text { local residents }\end{array}$ & $\begin{array}{l}\text { Anti-social } \\
\text { behaviour }\end{array}$ & 9.0 & 22.5 & 40.4 & 28.1 & 0.0 & 100 \\
\hline 6 & $\begin{array}{l}\text { Rowdiness, } \\
\text { fighting in the } \\
\text { street }\end{array}$ & $\begin{array}{l}\text { Anti-social } \\
\text { behaviour }\end{array}$ & 2.2 & 33.7 & 39.3 & 23.6 & 1.1 & 100 \\
\hline 7 & Vandalism & $\begin{array}{l}\text { Anti-social } \\
\text { behaviour }\end{array}$ & 12.4 & 39.3 & 30.3 & 15.7 & 2.2 & 100 \\
\hline 8 & Drug dealing & $\begin{array}{l}\text { Criminal } \\
\text { activity }\end{array}$ & 19.3 & 36.4 & 23.9 & 13.6 & 6.8 & 100 \\
\hline 9 & Other crime & $\begin{array}{l}\text { Criminal } \\
\text { activities }\end{array}$ & 14.1 & 36.5 & 31.8 & 7.1 & 10.6 & 100 \\
\hline 10 & $\begin{array}{l}\text { Overcrowding of } \\
\text { public spaces }\end{array}$ & $\begin{array}{l}\text { Perception of } \\
\text { place }\end{array}$ & 42.7 & 30.3 & 18.0 & 6.7 & 2.2 & 100 \\
\hline \multirow[t]{2}{*}{11} & $\begin{array}{l}\text { Driving out } \\
\text { existing small } \\
\text { businesses/small } \\
\text { shops }\end{array}$ & $\begin{array}{l}\text { Economics, } \\
\text { sustainability }\end{array}$ & 50.6 & 29.2 & 10.1 & 3.4 & 6.7 & 100 \\
\hline & Average & & 14.5 & 27.1 & 29.8 & 24.5 & 4.1 & 100 \\
\hline
\end{tabular}

$1=$ no problem; $2=$ small problem; $3=$ problem; $4+5=$ serious or extremely serious problem; $\mathrm{NA}=$ not applicable. 
serious. This is also despite the fact that since 2000 the number of night buses has been increased by $25 \%$ and that night bus fares have been made the same as during the day. Night bus services have also been put on in Brighton, a city well known for its night-time economy, which now has a 24-hour bus service. Manchester City Council has assisted its regional transport authority to encourage private bus operators to provide more services at night, through subsidies for new routes at night in the first few months of operation [37]. This has been so successful that other routes to outlying towns outside the conurbation are also now operating at night.

Although lack of transport was given prominence over crime as a serious issue, there is, nevertheless a link to crime. Research carried out in 1992 [38] demonstrated that queues for taxis and buses often form the flashpoint's for fights and scuffles. This has been later confirmed by both qualitative research carried out for the British Government's Home Office [39]. Focus group research with young people suggested that better public transport in and out of entertainment districts could reduce alcohol-related crime and disorder [40].

The second problem reported by $33.7 \%$ of the local authorities as serious or extremely serious is litter or rubbish on the streets. This was especially important for London boroughs and other urban areas. One Inner London authority reported making additional waste collections, as did a major coastal city. This issue is now regarded as so serious that central Government has introduced new legislation to cover commercial waste collection. Waste collection in itself can cause a further problem with regard to city centre sustainability, as there have been a number of instances where residents have complained about the noise created by late-night bottle collections [41].

The third problem is linked as it relates to the fouling of streets, by urination or worse. Among the local authorities $30 \%$ reported it as being serious or extremely serious. Public urination is not an offence but can be prohibited by local authority by law. Police are reluctant to take action against such low-level instances of disorder, because it takes officers away from more serious offences, such as assault. Public urination constitutes a health hazard. The acid in the urine also attacks certain types of paving stones, causing extra wear and tear on the streets. This problem has been exacerbated by the tendency for local authorities to close their public toilets during the day, let alone leaving them open at night [42].

The fourth most significant problem related to the perception of place and feelings of safety. The authorities that reported this as a problem were concentrated mainly in urban areas outside London. This may be because the concentration of activities and lights in central and inner parts of London may reduce perceptions of threat. One town council in south central England reported: 'A smart restaurant near the core would fail unless their customers are deposited and picked up from the door of the establishment'. A spa town commented that 'tourists do not venture out at night'. The domination of micro districts within town centres by a youthful age group was a common theme in responses to our survey. Academic research undertaken in two Welsh cities provides both qualitative and quantitative evidence for the fears that older people experience when going out at night. In particular 'drinking streets' are avoided [43]. In the central quarters of cities, entertainment and residential areas overlap or are located in close proximity. In spite of evidence that central quarters attract more cosmopolitan residents who are very often active actors in the night-time economy themselves, the problems of noise are reported. Noise disturbance to local residents came fifth on the list. It was the Inner London boroughs that recorded this as a serious problem. Presumably, the higher densities experienced in Inner London, where demand for housing is at a premium area factor. The impact of external noise emanating from people entering or leaving clubs and bars is relatively under-researched. Evidence from sound recordings taken in Old Compton Street in Soho, for example [44], demonstrate that where the noise of queues is experienced in a street from night clubs, decibel levels can reach a level equivalent to that of a pneumatic drill. Britain's relatively lax environmental protection legislation does not assist residents in this respect, because building regulations are not framed to protect buildings 
against external noises, unless they are in exceptional circumstances, such as the flight path of an airport.

Poor signage is also a problem, and one provincial city council reported that, because of this, customers from bars and night clubs tended to get lost and to follow routes through residential neighbourhoods. Another commented that it was difficult for its planning authority to decide "which venues create a positive impact on the city and those which cause additional noise and disturbance in partly residential areas'. There is other evidence from individual locations to provide support to these responses. In Romford, an Outer London borough, residents complained to their local council of night-time revellers dispersing through the residential streets that surround the town centre [45]. Residents in Headingley, a sub-centre of the major northern city of Leeds, also complained to the Parliamentary inquiry about the noise and vandalism that they endured, perpetrated by customers from four large local pubs [7].

Other problems that had been listed were not recorded as being serious or extremely serious in spite of being highlighted in the press or in secondary sources. For example, rowdiness and fighting on the street was not a typical night-time economy issue for Outer London boroughs. Vandalism, on the other hand, was considered to be more of a problem here, as well as in urban areas outside London.

Drug dealing is a problem for Inner London and other urban areas outside of London, whereas it did not attract high scores in rural areas and in the suburban Outer London boroughs. A detailed study carried out by the Inner London borough of Camden found that peaks in the offences of drug dealing were related to peaks in people exiting from clubs and bars (typically at 9 p.m., 11 p.m., and 1 a.m.) [46]. It seems probable that the density of pedestrians formed both a clientele and a 'shield' for dealers.

The overcrowding of pavements, which can feel threatening particularly to the elderly and may attract pickpockets, is more of a problem in outer London than in Inner London and other urban areas and it is not recorded as a problem at all in rural areas.

One of the issues that have been raised by residents in Soho is the driving out of existing small businesses by corporately owned bars and clubs who can pay high rents. This complaint was included in the question because the extinction of small businesses undermines the sustainability of town and city centres. This, however, was a problem that was regarded as the least serious overall and seemed only to apply to the Inner London authorities.

\section{RESPONSES TO PROBLEMS: BUILDING SUSTAINABILITY?}

The problems with the night-time economy arose so quickly that local authorities and local police forces were required to respond without the benefit of guidance from the central government. Anecdotal evidence had been gathered from the House of Commons Inquiry of some imaginative crossagency initiatives. A question was therefore asked about specific policies and strategies that had been developed in response to problems, other than changes to policies that were being developed any way, such as licensing strategies.

The most popular approach to improvements focused on policing to reduce crime and disorder (see Tables 5 and 6). Among the local authorities $77.5 \%$ chose improvements to CCTV systems as their most important response. This apparent discrepancy with the ranking of problems, where the perception of threats to safety came only fourth on the list with other more low-level crime and disorder issues following in sixth to ninth places might be explained by the offer of grants from the Home Office to install CCTV cameras. Furthermore, the linking of the CCTV cameras in pubs and clubs (Pubwatch) to a centrally run police CCTV control room encourages the involvement of the private sector in environmental management. There is some controversy as to the impacts of CCTV 
Table 5: Solutions to problems

\begin{tabular}{|c|c|c|c|c|c|c|c|}
\hline A & $\begin{array}{l}\text { Additional policing } \\
\text { required }\end{array}$ & Policing & 2.2 & 12.4 & 32.6 & 50.6 & 2.2 \\
\hline B & $\begin{array}{l}\text { Additional servicing of } \\
\text { area required }\end{array}$ & $\begin{array}{l}\text { Better management } \\
\text { required }\end{array}$ & 7.9 & 24.7 & 38.2 & 23.6 & 5.6 \\
\hline
\end{tabular}

Table 6: Is your authority proposing any new measures to improve the management of areas of intensive evening/night-time activities?

\begin{tabular}{|c|c|c|c|c|c|}
\hline & Measure & Type of measure & Yes & NA & Total \\
\hline 1 & $\begin{array}{l}\text { Improvements in surveillance } \\
\text { (CCTV) }\end{array}$ & $\begin{array}{l}\text { Pub and club watch schemes } \\
\text { directly linked to police CCTV }\end{array}$ & 77.53 & 22.47 & 100 \\
\hline 2 & $\begin{array}{l}\text { Improvements in/or partnership } \\
\text { with police (e.g. neighbourhood } \\
\text { wardens, community support } \\
\text { officer) }\end{array}$ & $\begin{array}{l}\text { Community safety strategies; } \\
\text { joint licensing enforcement } \\
\text { visits; community support } \\
\text { officers }\end{array}$ & 76.40 & 23.60 & 100 \\
\hline 3 & $\begin{array}{l}\text { Late-night economy partnership } \\
\text { with entertainment industry }\end{array}$ & $\begin{array}{l}\text { Multi-stakeholder working } \\
\text { groups }\end{array}$ & 50.56 & 49.44 & 100 \\
\hline 4 & Improvements in lighting & $\begin{array}{l}\text { Environmental improvements; } \\
\text { gating }\end{array}$ & 43.82 & 56.18 & 100 \\
\hline
\end{tabular}

on perceptions of safety and crime. This could explain the difference in enthusiasm for installing new systems between areas, with 100 deep rural areas favouring CCTV and Inner London which would have had has the highest density of CCTV cameras already displaying slightly more scepticism (63.4\%).

The second most popular initiative again involved crime, $76.4 \%$ of districts cited setting up new partnerships with the police or improving existing ones as new management response. All areas reported a high level of interest, but this was particularly significant for urban areas outside London. Approximately half of the respondents, $50.56 \%$, intended to set up working groups where representatives of the licensed trade, different local authority departments (licensing, environmental health, planning, cultural development) and other agencies, such as the police, the youth service and the health service, could meet and work together. Such initiatives might be seen as extending the concept of town centre management into the evening and night-time hours.

Over the last three years, many local authorities have indeed made imaginative partnerships that are primarily police-led and focused towards the licensed trade. Bolton, a small, former industrial town near Manchester, has appointed a town centre manager to operate at night. Manchester itself has one of the best regarded local multi-agency forums, Manchester Citysafe, which was started by the Greater Manchester Police [22]. Cheltenham has also set up a multi-agency forum [33]. Several cities have formulated 'visions' and 'strategies' for their centres at night-time, which have been produced through stakeholder consultation. Nottingham, a city centre that has experienced many problems, has now produced a vision and an action plan [47]. Leeds has adopted a similar approach. This includes environmental improvements such as gating off alleyways at night and cultural animation, which 
encourages evening festivals and outdoor fashion shows, to attract families to the town centre [7]. The relatively low response to making environmental improvements, $43.82 \%$, such as gating dark alleyways and improving lighting might be explained by the difference in response between rural and urban areas. Urban areas may have already carried out this work. Among the deep rural areas $75 \%$ considered it as a serious measure in comparison with only $27.3 \%$ in Outer London.

\section{COMMENTARY: DILEMMAS OF SUSTAINABILITY}

The survey highlighted the differences between town and city centres with regard to their geography. It was found that 'deep rural areas' were experiencing serious issues with regard to the expansion of their night-time economies and this was not just a problem for the big cities. This suggests that the planning of historic market towns, with their numerous pubs and hostelries, need to pay attention to this issue. Furthermore, although media interest has concentrated on crime and anti-social behaviour, for local authorities, the questions of infrastructure in the form of transport, cleansing and waste are equally severe.

One provincial city summed up this concern with the comment: 'Without doubt there has been a recent change of culture within the city centres where there has been a drastic increase in the number of licensed premises with no additional resources to deal with the issues that result.' At the moment, the resources for additional clean-up and policing are found from the public purse, from central government for policing and from the local council tax payers for cleansing. Additional transport can only be subsidised temporarily and therefore, in the long run, has to be selfsupporting. The time expended by local authority and police officers on multi-agency partnerships also draws on public expenditure. At the time of writing, the British Government has only implemented one solution to this fiscal problem and that is through the import of the North American solution of business improvement districts (BIDs). In this model, dependent on a majority vote, businesses on a designated area can vote for a compulsory extra tax that will pay for additional services. Twenty-two BID pilot areas have been declared in England and so far 10 positive votes to set up a BID have been made (see www.ukbids.org). The introduction of BIDs raises questions of social exclusion and private sector control [48], which so far, have not been addressed. Besides this, the government is intending, in micro districts, where there is exceptional crime and disorder, to declare an Alcohol Disorder Zone (Fig. 3), whereby the premises associated with

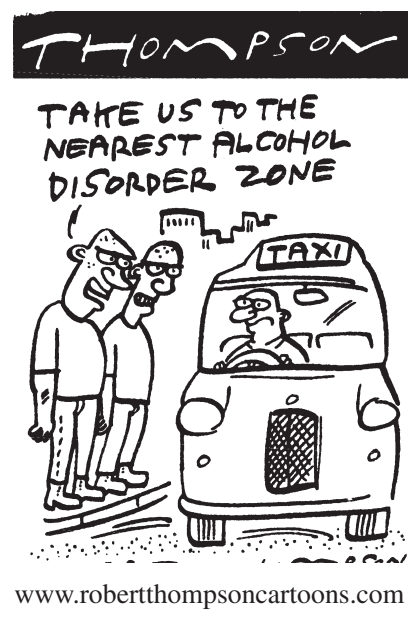

Figure 3: Alcohol Disorder Zone. Source: Observer, 23 January 2005. 
the night-time economy will be obliged to undertake a series of remedial measures, including contributions to the costs of extra policing [49]. This legislation has yet to go through Parliament. The entertainment and alcohol industry is opposed on what they see as an unfair tax, arguing that they already contribute millions to the Exchequer in excise duties (see The Publican, 4 March 2005, www.thepublican.com).

An additional concern is also that although central government planning policy has sought to encourage the return of residential uses into town centres, a significant number of authorities were reporting conflicts between residential and entertainment uses in terms of noise. The Commons Inquiry heard evidence that these problems were leading some residents to consider moving out of these centres entirely, thereby potentially undermining their sustainability as mixed-use centres.

On a more positive note, one of the concerns that had been raised about the expansion of the night-time economy was that it was driving out small businesses. There seemed little evidence that this was happening. The regenerative effects of expansion in the forms of creating jobs and therefore increasing prosperity were also noted by many respondents. From the point of view of encouraging the diversification of the evening economy, there was encouraging evidence of the appearance of new nonalcohol-based leisure activities, although this was in only a minority of town centres. Other centres bemoaned the problem, with one rural authority commenting: 'How can a local authority encourage cafes and retailers to continue in medium sized market towns where the businesses concerned do not/have not identified a commercial need?'

\section{COMMENTARY: INTERNATIONAL PERSPECTIVES}

It is difficult to assess whether the negative externalities associated with the English transformation of night life is peculiar to that country or part of a wider-scale phenomenon. Certainly, the transformation of city centres across the world into theatres of consumption has been widely reported and commented on $[48,50,51]$. There has also been an appraisal of the opportunities of the benefits of a growth in a new type of public culture [52, 53] with theorists such as Florida [54] making it the centre piece of his argument for a new type of economic development, the support of a 'creative class'. The negative aspects of a predominance of alcohol-based entertainment, as opposed to re-defined urban café culture, have received less international attention.

Criticism in Britain has come from commentators on health issues [26], who are less concerned with the physical location of alcohol consumption, which is where and how it happens, than with total levels of consumption and health effects such as disease and risky behaviour. The World Health Organisation has become alarmed by rises in overall alcohol consumption and its impacts on public health, social welfare and the criminal justice systems. Much of the evidence drawn upon for the WHO's most recently sponsored research review [55] comes from studies on the Nordic countries and the USA for discussion of the impacts of the locations and times of opening for on-licensed premises. These studies have mainly focused on impacts, such as levels of consumption and traffic accidents rather than environmental effects.

Commentary is further complicated by the different drinking cultures and legislative arrangements in each country. Anecdotally, southern European countries are regarded as having different drinking cultures to those in the north. There is evidence to bear this out. The European School Survey Project on Alcohol and other Drugs, carried out in 2001, showed that Danish teenagers (15-16 year olds) and other Northern European countries reported the highest levels of heavy drinking and drunkenness. There was a clear contrast between the four countries at the top of the ranking (Denmark 39\%, Finland $29 \%$, UK $28 \%$ and Ireland 27\%) and those at the bottom (France 3\%, Romania 3\%, Italy $2 \%$ and Cyprus 1\%). The percentages refer to the proportion of boys or girls who had been drinking 10 times or more in the last 12 months [56]. Clearly, northern European countries suffer more problems from the excess consumption of alcohol among young people than those in the south. 
Whether these national differences have an impact on town centres is less clear. Plant and Plant's [57] international review of the evidence of the impact of extended licensing hours found that when licensing was liberalised, residents in Reykavik complained of increased disturbance. The appearance of the city centre also suffered, with families and tourists coming out early on to the streets to encounter litter and intoxicated people leaving bars and clubs. Two years after liberalisation, the city council restricted serving hours at the request of the police and city centre steering group. The evidence from Australia presents a more complex picture. Extending opening hours in Perth by an hour contributed to an increase in crime, violence and drunken driving [58]. Conversely an attempt in Canberra to cut back from a 4 am terminal hour for nightclubs from 24 hour licensing had little effect [59]. A study of the planning and licensing arrangements for alcohol-related entertainment in four different European capitals, Berlin, Copenhagen, Dublin and London's West End, came to the conclusion that it was not the hours of opening that were the sole indicator of negative effects, but the total planning, building and licensing regime that was in operation [60]. The negative effects of a concentration of night-time activities were reported in all four cities, but the efficacy with which such effects could be managed and minimised depended on the different regulatory environment operating in each city.

Certainly, cities in the USA and Europe that are cited as having few problems with licensed premises [61] do appear in fact to do so. In Barcelona, residents in the Raval and Ribera districts display signs outside their flats asking customers leaving the bars and restaurants to leave quietly and not to urinate in the streets. Barcelona also has had an annual noise initiative, whereby the city council distributes drinks coasters (Fig. 4) and displays posters reminding the patrons of bars to be quiet. This happens not only in the tourist areas of the Ciutat Vella (old town) but in eight other neighbourhoods in the city [62]. In New York City, a debate has been continuing about their dancing laws (liquor licensing is regulated by the state). Residents in the Chelsea district have been annoyed by the customers of nightclubs, some of which hold 3,000 customers, coming out onto the streets to smoke [63]. Particular problems may be experienced when the cultural attitudes from northern European drinking cultures are exported overseas, as a result of tourism or sporting events. Moore's [64] study of a small Greek town demonstrates that successive waves of foreign tourism have altered local drinking patterns among both men and women, loosening social restrictions. Low-cost flights are also spreading the 'stag and hen' party phenomenon to the countries of the former Eastern bloc, such as Estonia. While reports of the impacts of drunken behaviour reach newspaper headlines, there seems little systematic research on the impacts. Presumably, the town and city councils involved seek to dispel any adverse

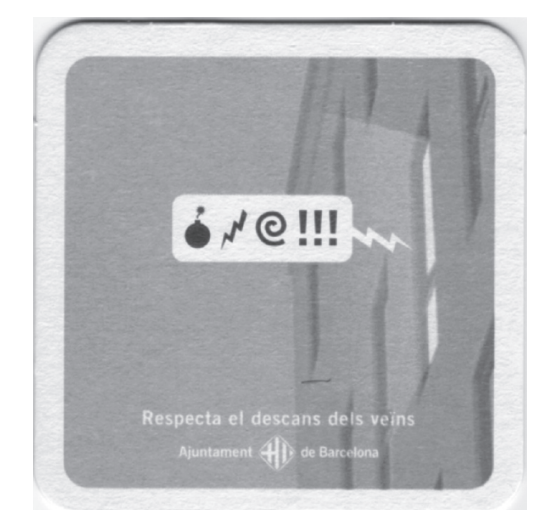

Figure 4: Coaster used as part of noise campaign, Ajuntament de Barcelona, 2002. 
publicity, for fear of the impact on their local economies, which leads back to the central argument of this article, that of sustainability.

\section{CONCLUSIONS}

At end of the 1980s, English town and city centres were considered a problem in terms of their economic sustainability, because of a lack of people and activities. Local authorities have been keen to encourage the expansion of evening and night-time activities, but it is the alcohol-based late-night activities that have expanded the most. The article has noted the difficulties of defining the term 'urban sustainability' and has pointed out that definitions may vary depending upon who or what is to be sustained. The lack of convergence between the goals of economic growth, environmental quality, and social continuity has been noted.

The evidence brought forward from our questionnaire survey of local authorities illustrated the extent to which an expansion of alcohol-based night life threatens the overall sustainability of town centres after mid-evening through the demands placed on local services and through heightening perceptions environmental degradation, noise, threat, and lack of safety. Despite the increased turnover and profit that is being generated by private businesses, costs are falling on central and local government and hence on local and national taxes. These conflicts point towards the need for local authorities to adopt a stronger vision for their town centres at night. Here, the benefits brought through an increased number of jobs and a rise of the levels of vitality need to be balanced against the longer-term needs of the micro-district.

This suggests that whilst an expansion in night life is generally welcome, the negative externalities cannot be ignored. There are few research studies that seek systematically to assess these negative impacts and the means to counteract them. More investigation needs to be carried out within specific localities as to potential benefits and negative effects. The means to maximise the former and minimise the latter is critical to the future sustainability of many town and city centres, both in England and abroad.

\section{REFERENCES}

[1] Comedia in association with the Calouste Gulbenkian Foundation, Out of Hours: A Study of Economic, Social and Cultural Life in Twelve Town Centres Across the UK, COMEDIA: London, 1991.

[2] Heath, T., The twenty-four hour city concept - a review of initiatives in British cities. Journal of Urban Design, 2(2), pp. 193-204, 1997.

[3] Hobbs, D., Hadfield, P., Lister, S. \& Winlow, S., Bouncers: Violence and Governance in the Night-Time Economy, Oxford University Press: Oxford, 2003.

[4] Hollands, R. \& Chatterton, P., Producing nightlife in the new urban entertainment economy: corporatization, branding and market segmentation. International Journal of Urban and Regional Research, 27(2), pp. 361-385, 2003.

[5] Blair, I., When drinking is a crime. New Statesman (One too many? Special Supplement), p. xxv, $15,2004$.

[6] House of Commons ODPM: Housing, Planning, Local Government and the Regions Committee, The Evening Economy and the Urban Renaissance: Twelfth Report of Session 2002-3 HC396-1, The Stationery Office: London, 2003.

[7] House of Commons ODPM: Housing, Planning, Local Government and the Regions Committee, The Evening Economy and the Urban Renaissance: Memoranda submitted to the Urban Affairs Sub-committee HC396-II, The Stationery Office: London, 2003. 
[8] NSF (National Science Foundation), Towards a Comprehensive Geographical Perspective on Urban Sustainability, Final report of 1998 National Science Foundation Workshop on Urban Sustainability, January 2000.

[9] WCED (World Commission on Environment and Development, Our Common Future (Brundtland Report), Oxford University Press: Oxford, 1987.

[10] Campbell, S., Green cities, growing cities, just cities? Urban planning and the contradictions of sustainable development. Journal of the American Planning Association, 62, pp. 296-312, 1996.

[11] Drakakis-Smith, D., Third world cities: sustainable urban development. Urban Studies, 32, pp. 659-678, 1995.

[12] Drakakis-Smith, D., Third world cities: sustainable urban development. II: Population, labour and poverty. Urban Studies, 33, pp. 673-701, 1996.

[13] Drakakis-Smith, D., Third world cities: sustainable urban development. III: Basic needs and human rights. Urban Studies, 34, pp. 797-823, 1997.

[14] Healey, P., \& Shaw, T., Planners, plans and sustainable development, Regional Studies, 27, pp. 769-76, 1993.

[15] Munton, R., Engaging sustainable development: some observations on progress in the UK, Progress in Human Geography, 21, pp. 147-63, 1997.

[16] Whitehead, M., (Re)analysing the sustainable city: nature, urbanisation and the regulation of socio-environmental relations in the UK. Urban Studies, 40(7), pp. 1183-1206, 2003.

[17] Jacobs, J., The Death and Life of Great American Cities, Vintage: New York, 1961.

[18] Montgomery, J., The evening economy of cities. Town and Country Planning, 63, pp. 302-307, 1994.

[19] Bianchini, F., Night cultures, night economies. Planning Practice and Research, 10(2), pp. 121-126, 1995.

[20] Urban Task Force, Towards an Urban Renaissance, E\&F Spon: London, 1999.

[21] Couch, C., \& Dennemann, A., Urban regeneration and sustainable development in Britain: the example of the Liverpool Ropewalks Partnership. Cities, 17(2), pp. 137-147, 2000.

[22] ODPM (Office of the Deputy Prime Minister), How to Manage Town Centres, ODPM: London, 2005.

[23] Craig, G., An urban-rural categorisation for wards and local authorities. Population Trends, 47, pp. 6-11, 1987.

[24] Bromley, G., Homelessness in Rural England: Statistical Update 1992/93, Rural Development Commission: London \& Salisbury, 1994.

[25] Tiesdell, S. \& Slater, A.M., Managing Urban Vitality: Spatial and Temporal Control in the Evening and Night-Time Economy, Report for the RICS Foundation, University of Aberdeen: Aberdeen, December 2003.

[26] Drummond, D., An alcohol strategy for England: the good, the bad and the ugly. Alcohol and Alcoholism, 39(5), pp. 377-339, 2004.

[27] DCMS (Department of Culture, Media and Sport), Statistical Bulletin: Liquor Licensing England and Wales July 2003-June 2004, DCMS: London, 2004.

[28] Hadfield, P., Lister, S., Hobbs, D. \& Winlow, S., The '24-Hour City' - condition critical? Town and Country Planning, 70(11), pp. 300-302, 2001.

[29] House of Commons: Home Office, 5th Report on Anti-Social Behaviour: Memoranda submitted to the Home Affairs Select Committee, HC 80-II, The Stationery Office: London, 2005. www.publications.parliament.uk/pa/cm200405/cmselect/cmhaff/80ii/80we01.htm 
[30] City of Westminster, Statement of Licensing Policy Consultation Draft, Westminster City Council: London, August 2004.

[31] Chatterton, P. \& Hollands, R., Theorising urban playscapes: producing, regulating and consuming youthful nightlife city spaces. Urban Studies, 39(1), pp. 95-116, 2002.

[32] GLA Economics, Spending Time: London's Leisure Economy, Greater London Authority: London, 2003.

[33] Cheltenham Night Time Economy Working Group, Cheltenham's Night Time Economy Strategy 2004-2007 (6 July), Cheltenham Borough Council: Cheltenham, 2004.

[34] DoE(Department of the Environment), Revised Planning Policy Guidance Note 6: Town Centres and Retail Development, HMSO: London 1996. Now replaced by Office of the Deputy Prime Minister, Planning Policy Statement 6: Planning for Town Centres, The Stationery Office: London, 2005.

[35] Hillier, B., Can streets be made safe? Urban Design International, 9(1), pp. 31-45, 2004.

[36] Urban Task Force, Towards a Strong Urban Renaissance, Countryside Properties \& Igloo: London, 2005.

[37] Roberts, M., Good Practice in Managing the Evening and Night-time Economies: A Literature Review from an Environmental Perspective, Office of the Deputy Prime Minister: London, 2004.

[38] Marsh, P. \& Fox Kibby, K., Drinking and Public Disorder: A Report of Research Conducted for the Portman Group by MCM Research, The Portman Group: London, 1992.

[39] Richardson, A., Budd, T., Engineer, R., Philips, A., Thompson, J. \& Nicholls, J., Drinking, Crime and Disorder: Findings from the Youth Lifestyles Survey Paper No. 185, Home Office: London, 2003 (www.homeoffice.gov.uk).

[40] Engineer, R., Philips, A., Thompson, J. \& Nicholls, J., Drunk and Disorderly: A Qualitative Study of Binge Drinking Among 18-24-Year Olds. Home Office Research study no.262, Home Office: London, 2003.

[41] Central Cities Institute, Licensing Reform: A Cross-Cultural Comparison of Rights, Responsibilities and Regulation, University of Westminster: London, 2002.

[42] Greed, C., Inclusive Urban Design: Public Toilets, Architectural Press: Oxford, 2003.

[43] Bromley, R., Thomas, C. \& Millie, A., Exploring safety concerns in the night-time city. Town Planning Review, 71(1), pp. 71-96, 2001.

[44] Roberts, M. \& Turner, C., Conflicts of liveability in the 24-hour city: Learning from 48 hours in the life of London's Soho. Journal of Urban Design, 10(2), pp. 171-193, 2005.

[45] Eastaff, J., A night time economy strategy for Romford, unpublished MA Thesis, University of Westminster: London, 2005.

[46] Mayor of London \& Camden, L.B., A Managed Approach to the Night Time Economy in Camden: Research Study, Greater London Authority: London, 2004.

[47] www.nottinghamcity.gov.uk/sitemap/wt_safe_in_nottingham.

[48] Zukin, S., The Cultures of Cities, Blackwell: Oxford, 1995.

[49] DCMS (Department of Culture, Media and Sport, Office of the Deputy Prime Minister and the Home Office) et al., Drinking Responsibly: the Government's Proposals, London: The Stationery Office, January, 2005 (www.crimereduction.gov.uk/alcohol03.htm).

[50] Hannigan, J., Fantasy City: Pleasure and Profit in the Postmodern Metropolis, Routledge: London, 1998.

[51] Smith, N., The New Urban Frontier: Gentrification and the Revanchist City, Routledge: London, 1996. 
[52] Latham, A., Urbanity, lifestyle and making sense of the new urban cultural economy: notes from Auckland, New Zealand. Urban Studies, 40(9), pp. 1699-1724, 2003.

[53] Ley, D., The New Middle Class and the Remaking of the Central City, Oxford University Press: Oxford, 1996.

[54] Florida, R., The Rise of the Creative Class: And How It is Transforming Work, Leisure, Community and Everyday Life, Basic Books: New York, 2002.

[55] Babor, T. et al., Alcohol: No Ordinary Commodity; Research and Public Policy, Oxford University Press: Oxford, 2003.

[56] Plant, M. \& Miller, M., Young people and alcohol: an international insight. Alcohol and Alcoholism, 36(6), pp. 513-515, 2001.

[57] Plant, E. \& Plant, M., A 'leap in the dark'? Lessons for the United Kingdom from past extensions of bar opening hours. International Journal of Drug Policy, 16(6), pp. 363-368, 2005.

[58] Chikritzis, T. \& Stockwell, T., The impact of later trading hours for Australian public houses (hotels) on levels of violence. The Journal of Studies on Alcohol, 63, pp. 591-599, 2002.

[59] Walker, J. \& Biles, D., An Evaluation of the Trial of Restricted Liquor Trading Hours in the Australian Capital Territory 1997-97, John Walker Consultancy Services: Queanbeyan, NSW, 1997.

[60] Roberts, M., Greenfield, S., Osborn, G. \& Turner, C., A continental ambience? Lessons in managing alcohol related evening and night-time entertainment from four European capitals. Urban Studies, 43(7), pp. 1105-1125, 2006.

[61] Town Centres Ltd. (in association with Chesterton plc and PRP Planning), West End Entertainment Impact Study, Westminster City Council: London, 2001.

[62] Interview with Noise Reduction Team, Ajuntament de Barcelona, 7 November 2002.

[63] Interview, Department of Consumer Affairs, New York City, 15 March 2004.

[64] Moore, R.S., Gender and alcohol use in a Greek tourist town. Annals of Tourism Research, 22(2), pp. 300-313, 1995. 